\title{
ANALISIS TINGKAT BERPIKIR KREATIF SISWA DALAM MENYELESAIKAN SOAL LUAS GABUNGAN PADA MATERI BANGUN DATAR DI SMP NEGERI 8 SALATIGA KELAS VII
}

\author{
Margareta Widi Trisna Putri', Novisita Ratu ${ }^{2}$ \\ ${ }^{1}$ Pendidikan Matematika, Universitas Kristen Satya Wacana Salatiga, 202014046@student.uksw.edu \\ ${ }^{2}$ Pendidikan Matematika, Universitas Kristen Satya Wacana Salatiga, novisita.ratu@staff.uksw.edu
}

\section{INFO ARTIKEL}

Riwayat Artikel:

Diterima: 07-03-2018

Disetujui: 26-03-2018

\section{Kata Kunci:}

Tingkat kemampuan berpikir kreatif, segitiga dan segiempat

\section{A. LATAR BELAKANG}

Pembelajaran matematika di sekolah tidak hanya berkaitan dengan penguasaan materi matematika sebanyak-banyaknya, namun juga untuk mencapai tujuantujuan yang lebih tinggi misalnya mengembangkan kemampuan berpikir siswa (Mahmudi, 2010:349).

Pentingnya pengembangan kreativitas pada matematika juga terdapat pada Kurikulum 2013. Hal ini terbukti adanya Peraturan Pemerintah Nomor 17 Tahun 2010 dalam Kurikulum 2013 tentang pengelolaan Penyelenggaraan Pendidikan, yang menyebutkan bahwa tujuan penyelenggaraan pendidikan dasar dan menengah yaitu membangun landasan bagi berkembangnya potensi siswa agar menjadi manusia yang berilmu, cakap, kritis, kreatif, dan inovatif. Kurikulum tersebut juga menyebutkan bahwa salah satu kriteria mengenai kualifikasi kemampuan lulusan yang harus dimiliki oleh siswa yaitu memiliki kemampuan berpikir kreatif dalam ranah abstrak dan konkret sesuai dengan yang dipelajari di sekolah dan sumber lain yang sejenis. Pada matematika, kemampuan berpikir kreatif matematis merupakan produk dari kreativitas matematika sedangkan kreatif merupakan kegiatan dalam pembelajaran yang diarahkan untuk mendorong atau memunculkan kreativitas siswa.
Berpikir kreatif merupakan suatu kebiasaan dari pikiran yang dilatih dengan memperhatikan intuisi, menghidupkan imajinasi, mengungkapkan kemungkinankemungkinan baru, membuat sudut pandang yang menakjubkan dan membangkitkan ide-ide yang tak terduka (Usman, 2014).

Berpikir kreatif matematis merujuk pada kemampuan untuk menghasilkan solusi bervariasi yang bersifat baru terhadap masalah matematika yang bersifat terbuka menurut Livne (2008) .

Siswono (2008: 39) mengungkapkan bahwa salah satu cara yang dapat mendorong kemampuan berpikir kreatif dalam pembelajaran matematika adalah dengan terbiasa memecahkan masalah. Siswa tidak hanya diberikan teoriteori atau rumus-rumus matematika, tetapi siswa dilatih dan dibiasakan untuk belajar memecahkan masalah sehingga pemahaman siswa terhadap suatu konsep menjadi lebih bermakna.

Hasil survey yang dilakukan oleh TIMSS (Trend in International Mathematics and Sciences Study) pada tahun 2011 mencatat bahwa data prestasi matematika siswa kelas VIII SMP Indonesia berada di peringkat ke-36 dari 40 negara dengan skor 386 dari skor rata-rata internasional 500. Hasil TIMSS ini mengungkapkan bahwa kemampuan 
berpikir kreatif matematis siswa Indonesia untuk soal-soal tidak rutin sangat lemah, namun relatif baik dalam menyelesaikan soal-soal fakta dan prosedur (Kartiningsih, 2014, h. 3). Berdasarkan hasil tes PISA (Program for International Student Assessment) tahun 2012 tentang matematika, siswa kelas VIII SMP Indonesia berada pada peringkat 64 dari 65 negara dengan skor 375 dari nilai standar rata-rata yang ditetapkan oleh PISA adalah 500 (OECD, 2012).

Mengembangkan kemampuan berpikir logis, analitis, sistematis, kritis, maupun bekerjasama sudah lama menjadi fokus dan perhatian pendidikan matematika di sekolah, karena hal itu berkaitan dengan sifat dan karakteristik keilmuan matematika (Siswono, 2009). Silver (1997) menjelaskan bahwa untuk menilai kemampuan berpikir kreatif anak-anak dan orang dewasa dapat dilakukan dengan menggunakan "The Torrance Test of Creative Thingking (TTCT)". Tiga komponen kunci yang dinilai dalam berpikir kreatif menggunakan TTCT adalah kefasihan (fluency), fleksibilitas (flexibility) dan kebaruan (novely). Siswono mengadaptasi alat ukur tes dari dari Silver tersebut dengan menggunakan tiga komponen kunci yang sama. Kefasihan (fluency)mengacu pada kemampuan siswa dalam memberikan bermacam-macam jawaban, fleksibilitas (flexibility) mengacu pada kemampuan siswa dalam menyelesaikan masalah tidak hanya satu cara tetapi bisa memberikan cara lain, dan kebaruan (novelty) mengacu pada kemampuan siswa mengajukan suatu masalah yang berbeda dari masalah yang diajukan sebelumnya.

Untuk mengetahui tingkat kekreatifan seseorang, perlu adanya penilaian terhadap kemampuan berpikir kreatif pada orang tersebut. Penilai tersebut harus meliputi tiga aspek berpikir kreatif menurut Siswono yaitu kefasihan, fleksibelitas, dan kebaruan. Setiap aspek memiliki kriteria kemampuan yaitu sebagai berikut:

TABEL 1.

INDIKATOR BERPIKIR KREATIF

\begin{tabular}{|l|l|}
\hline $\begin{array}{c}\text { Karakteristik } \\
\text { Berpikir Kreatif }\end{array}$ & \multicolumn{1}{|c|}{$\begin{array}{c}\text { Indikator Berpikir Kreatif dalam } \\
\text { Pengajuan Masalah }\end{array}$} \\
\hline $\begin{array}{l}\text { Kefasihan } \\
\text { Fluency) }\end{array}$ & $\begin{array}{l}\text { siswa mampu menyelesaikan masalah } \\
\text { matematika yang beragam (lebih dari } \\
\text { satu) dengan penyelesaian benar. }\end{array}$ \\
\hline $\begin{array}{l}\text { Fleksibilitas } \\
\text { (Flexibility) }\end{array}$ & $\begin{array}{l}\text { siswa mampu menyelesaikan masalah } \\
\text { yang mempunyai cara penyelesaian yang } \\
\text { berbeda-beda. }\end{array}$ \\
\hline $\begin{array}{l}\text { Kebaruan } \\
\text { (Originality) }\end{array}$ & $\begin{array}{l}\text { siswa mampu menyelesaikan masalah } \\
\text { yang berbeda atau baru (masalah yang } \\
\text { diajukan siswa berbeda dengan siswa } \\
\text { yang lainnya atau jarang diajukan siswa } \\
\text { yang lain). }\end{array}$ \\
\hline
\end{tabular}

Kemampuan berpikir kreatif seseorang memiliki tingkatan menurut Siswono (2011). Tingkatan yang dimaksud sesuai karya yang dihasilkan. Oleh sebab itu digunakan Tingkat Kemampuan Berpikir Kreatif (TKBK) siswa. Tabel Tingkat Kemampuan Berpikir Kreatif adalah sebagai berikut.
TABEL 2.

TINGKAT KEMAMPUAN BERPIKIR KREATIF

\begin{tabular}{|c|l|}
\hline $\begin{array}{c}\text { Tingkat } \\
\text { Kemampuan }\end{array}$ & \multicolumn{1}{|c|}{ Karakteristik } \\
\hline $\begin{array}{c}\text { Tingkat 4 (Sangat } \\
\text { Kreatif) }\end{array}$ & $\begin{array}{l}\text { Peserta didik mampu menunjukkan } \\
\text { kefasihan, fleksibilitas, dan kebaruan } \\
\text { atau kebaruan dan fleksibilitas dalam } \\
\text { memecahkan masalah. }\end{array}$ \\
\hline Tingkat 3 (Kreatif) & $\begin{array}{l}\text { Peserta didik mampu menunjukkan } \\
\text { kefasihan dan kebaruan atau kefasihan } \\
\text { dan fleksibilitas dalam memecahkan } \\
\text { masalah. }\end{array}$ \\
\hline $\begin{array}{c}\text { Tingkat 2 (Cukup } \\
\text { Kreatif) }\end{array}$ & $\begin{array}{l}\text { Peserta didik mampu menunjukkan } \\
\text { kebaruan atau fleksibilitas dalam } \\
\text { memecahkan masalah. }\end{array}$ \\
\hline $\begin{array}{c}\text { Tingkat 1 (Kurang } \\
\text { Kreatif) }\end{array}$ & $\begin{array}{l}\text { Peserta didik mampu menunjukkan } \\
\text { kefasihan dalam memecahkan masalah. }\end{array}$ \\
\hline $\begin{array}{c}\text { Tingkat 0 (Tidak } \\
\text { Kreatif) }\end{array}$ & $\begin{array}{l}\text { Peserta didik tidak mampu menunjukkan } \\
\text { ketiga aspek dalam memecahkan } \\
\text { masalah. }\end{array}$ \\
\hline
\end{tabular}

\section{B. METODE PENELITIAN}

Penelitian ini adalah penelitian deskriptif kualitatif untuk menganalisis tingkat kemampuan berpikir kreatif dalam menyelesaikan soal luas gabungan pada materi bangun datar di SMP Negeri 8 Salatiga kelas VII.

Penentuan subjek penelitian ini menggunakan teknik purposive sampling yaitu teknik pengambilan sampel dengan pertimbangan tertentu (Sugiyono, 2012:300). Subjek dalam penelitian ini meliputi 3 siswa kelas VII yang berkemampuan tinggi, sedang, rendah di SMP Negeri 8 Salatiga.

Metode pengumpulan data yang digunakan adalah metode tes, metode wawancara, dan dokumentasi. Langkah awal dalam penelitian ini adalah melakukan metode tes, metode yang dilakukan adalah dengan memberikan soal tes kemampuan berpikir kreatif kepada siswa. Langkah selanjutnya adalah teknik wawancara, wawancara yang digunakan pada penelitian ini dengan mengajukan pertanyaan-pertanyaan yang disusun secara sistematis. Langkah yang terakhir adalah metode dokumentasi, metode dokumentasi diambil dari hasil tes kemampuan berpikir kreatif siswa

Salah satu teknik yang dapat digunakan untuk memeriksa keabsahan data adalah dengan triangulasi. Peneliti menggunakan triangulasi teknik dan triangulasi waktu. Analisis data dalam penelitian ini meliputi reduksi data, penyajian data dan penarikan kesimpulan.

\section{HASIL DAN PEMBAHASAN}

Terdapat tiga indikator kemampuan berpikir kreatif menurut Siswono yaitu kefasihan, fleksibilitas, dan kebaruan. Siswono juga mengungkapkan bahwa terdapat 5 tingkat kemampuan berpikir kreatif (TKBK) yaitu TKBK 4 (sangat kreatif), TKBK 3 (kreatif), TKBK 2 (cukup kreatif), TKBK 1 (kurang kreatif) dan TKBK 0 (tidak kreatif). Berdasarkan hasil penelitian menunjukkan bahwa terdapat perbedaan dari masing-masing tingkat kemampuan berpikir kreatif pada materi luas gabungan 
segitiga dan segiempat. Subjek pada tingkat tinggi mampu memperlihatkan beberapa indikator berpikir kreatif sedangkan pada tingkat yang lebih rendah subjek belum mampu memperlihatkan indikator kemampuan berpikir kreatif yang ada.

Subjek FQ memiliki tingkat kemampuan berpikir kreatif 2
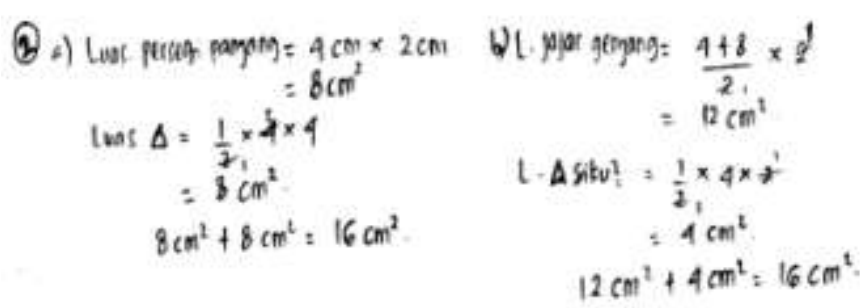

Gambar 1. Hasil Pekerjaan Soal No.2

Subjek yang termasuk dalam TKBK 2 (cukup kreatif), menunjukkan bahwa subjek mampu memperlihatkan satu indikator kemampuan berpikir kreatif yaitu fleksibilitas. Subjek FQ mampu memberikan alternatif jawaban dengan baik, seperti yang terlihat pada Gambar 1. Subjek menunjukkan cara lain untuk menentukan luas bangun yang diarsir, bukan dengan rumus biasa yaitu menjumlahkan luas persegi panjang dan luas segitiga saja, dimana selanjutnya dengan menjumlahkan luas jajargenjang dan luas segitiga siku-siku. Hal ini diperkuat dengan wawancara sebagai berikut:

M : Coba ceritakan kembali apa yang kamu pahami dari soal tersebut!

F : : (membaca soal no.2)

M : Apakah kamu bisa menyebutkan hal-hal yang diketahui dari soal?

F : Ya. Panjang AB, panjang BD, panjang EF, panjang $\mathrm{FG}$, panjang $\mathrm{CD}$, panjang $\mathrm{HF}$, panjang $\mathrm{FI}$, dan panjang $\mathrm{BD}$

M : Apa saja yang ditanyakan dari soal tersebut?

$\mathrm{F} \quad$ : Luas gambar yang diarsir

M : Pengetahuan apa saja yang kamu dapat gunakan untuk menjawab soal tersebut?

F : eeehh menggunakan luas persegi panjang ditambah luas segitiga atau luas jajargenjang ditambah luas segitiga siku-siku

M : Mengapa kamu memilih pengetahuan itu ?

F : Menurut aku ini cara yang lebih mudah

M : Jelaskan langkah-langkah yang kamu gunakan untuk menjawab soal tersebut!

F : 1. luas persegi panjang $4 \mathrm{~cm} \times 2 \mathrm{~cm}=8 \mathrm{~cm}^{2}$, luas segitiga $\frac{1}{2} \times 4 \times 4=8 \mathrm{~cm}^{2}$, luas persegi panjang ditambah luas segitiga sama dengan $8 \mathrm{~cm}^{2}+$ $8 \mathrm{~cm}^{2}=16 \mathrm{~cm}^{2}$

2. luas jajargenjang $\frac{4+8}{2}=12 \mathrm{~cm}^{2}$, luas segitiga siku-siku $\frac{1}{2} \times 4 \times 2=4 \mathrm{~cm}^{2}$, luas jajargenjang ditambah luas segitiga siku-siku sama dengan $12 \mathrm{~cm}^{2}+4 \mathrm{~cm}^{2}=16 \mathrm{~cm}^{2}$
$\mathrm{M}$

: Apakah kamu yakin dengan langkah-langkah yang kamu pikirkan ? Mengapa?

F : Iya... karena hal itu adalah hal yang lebih mudah

M : Apakah kamu hanya bisa menyebutkan 2 saja ya ? F : Iya

Hal tersebut menunjukkan bahwa subjek FQ memiliki fleksibilitas dalam dirinya.

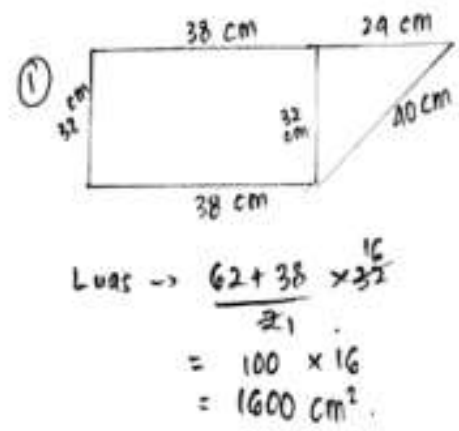

Gambar 2. Hasil Pekerjaan Soal No.1

Fleksibilitas yang dimiliki subjek FQ tidak didukung oleh kefasihan dalam menyelesaikan soal. Sebagaimana terlihat pada Gambar 2, subjek FQ mampu memberikan 1 bangun gabungan saja. Hal ini diperkuat dengan wawancara sebagai berikut:

M : Coba ceritakan kembali apa yang kamu pahami dari soal tersebut !

F : (membaca soal no.1)

M : Apakah kamu bisa menyebutkan hal-hal yang diketahui dari soal ?

F : Iya

M : Apa saja yang ditanyakan dari soal tersebut ?

F : Ehm.. nama bangun datar penyusunnya dan beserta ukurannya

M : Pengetahuan apa saja yang kamu dapat gunakan untuk menjawab soal tersebut?

F : Ehm.. teorema phytagoras dan luas trapesium

M : Mengapa kamu memilih pengetahuan itu ?

F : : Lebih mudah untuk mengeceknya

M : Jelaskan langkah-langkah yang kamu gunakan untuk menjawab soal tersebut !

F : Misal panjang persegi panjang $38 \mathrm{~cm}$ dan lebar $32 \mathrm{~cm}$ ehhh sisi miring segitiga $40 \mathrm{~cm}$ dan sisi satunya segitiga $24 \mathrm{~cm}$ maka luas trapesium $\frac{62+38}{2} \times 32=1600 \mathrm{~cm}^{2}$

M : Apakah kamu yakin dengan langkah-langkah yang kamu pikirkan? Mengapa?

F :Ya... eehhh karena dengan rumus luas jajargenjang lebih mudah untuk mengerjakannya

: Apakah kamu hanya bisa menyebutkan 1 saja ya ? : Iya

Hal tersebut menunjukkan bahwa subjek FQ belum mampu memberikan bermacam-macam jawaban sehingga indikator kefasihan belum mampu dimunculkan. 


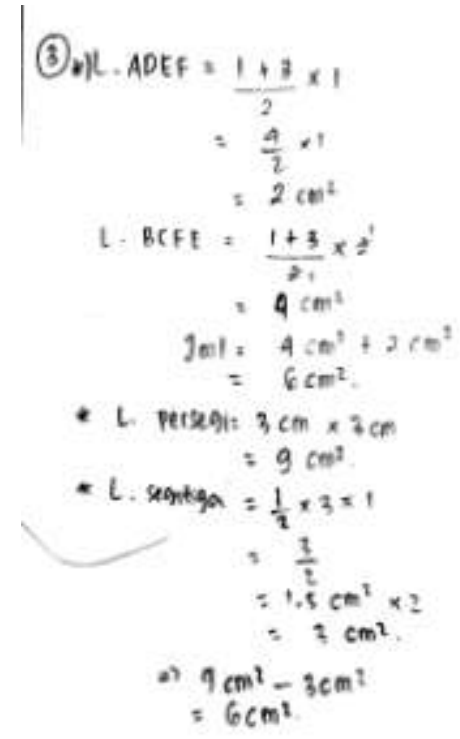

Gambar 3. Hasil Pekerjaan Soal No.3

Subjek FQ juga belum mampu menunjukkan adanya kebaruan dalam dirinya, ini dapat dilihat dari jawaban subjek seperti pada Gambar 3. Subjek FQ hanya memberikan jawaban yang terbilang masih umum dan belum baru. Hal ini diperkuat dengan wawancara sebagai berikut:

$\mathrm{M}$

: Coba ceritakan kembali apa yang kamu pahami dari soal tersebut!

F : : (membaca soal no.3)

M : Apakah kamu bisa menyebutkan hal-hal yang diketahui dari soal?

F : : Iya

M : Apa saja yang ditanyakan dari soal tersebut?

F : Luas yang diarsir

M : Pengetahuan apa saja yang kamu dapat gunakan untuk menjawab soal tersebut?

F : : Luas trapesium dan luas segitiga

M : Mengapa kamu memilih pengetahuan itu ?

F $\quad$ : Lebih mudah untuk mengerjakan

M : Jelaskan langkah-langkah yang kamu gunakan untuk menjawab soal tersebut !

$\mathrm{F}$ : 1. Luas $\mathrm{ADEF}=\frac{1+3}{2} \times 1=2 \mathrm{~cm}^{2}$, Luas $\mathrm{BCFE}=$ $\frac{1+3}{2} \times 2=4 \mathrm{~cm}^{2}$, jumlahnya $4 \mathrm{~cm}^{2}+2 \mathrm{~cm}^{2}=6 \mathrm{~cm}^{2}$

2. Luas persegi $=3 \mathrm{~cm} \times 3 \mathrm{~cm}=9 \mathrm{~cm}^{2}$, luas segitiga $\frac{1}{2} \times 2 \times 3 \times 1=3 \mathrm{~cm}^{2}, 9 \mathrm{~cm}^{2}-3 \mathrm{~cm}^{2}=$ $6 \mathrm{~cm}^{2}$

M : Apakah kamu yakin dengan langkah-langkah yang kamu pikirkan ? Mengapa?

F : Iya.. Menurut aku ini jawaban yang paling benar

M : Apakah kamu hanya bisa menyebutkan 2 saja ya?

F : : Iya

Hal tersebut subjek FQ tidak mampu membuat jawaban yang berbeda.
Subjek AS memiliki tingkat kemampuan berpikir kreatif 1

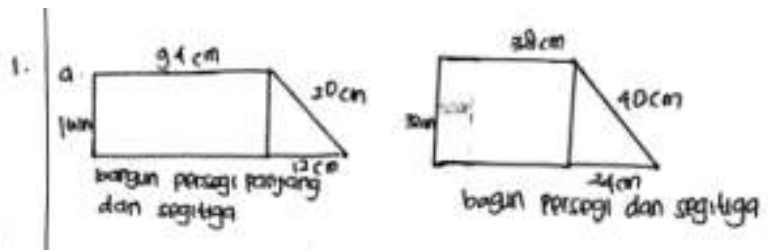

Gambar 4. Hasil Pekerjaan Soal No.1

Subjek yang termasuk dalam TKBK 1 (kurang kreatif), menunjukkan bahwa subjek mampu memperlihatkan satu indikator kemampuan berpikir kreatif yaitu kefasihan. Berbeda dengan TKBK 2 subjek pada tingkat ini hanya mampu memperlihatkan kefasihan dalam menjawab, ini dapat dilihat pada Gambar 4. Subjek AS mampu memberikan 2 bangun gabungan yang berbeda ukuran dan luas yang sesuai dengan yang ditanyakan. Hal ini diperkuat dengan wawancara sebagai berikut:

M : Coba ceritakan kembali apa yang kamu pahami dari soal tersebut!

A : (membaca soal no.1)

M : Apakah kamu bisa menyebutkan hal-hal yang diketahui dari soal ?

A : Iya

M : Apa saja yang ditanyakan dari soal tersebut?

A : Menyebutkan nama bangun datar jika luasnya diketahui

M : Pengetahuan apa saja yang kamu dapat gunakan untuk menjawab soal tersebut?

A : Menggunakan luas, luas segitiga dan segiempat

M : Mengapa kamu memilih pengetahuan itu ?

A : Karena menurut saya itu lebih mudah

M : Jelaskan langkah-langkah yang kamu gunakan untuk menjawab soal tersebut!

A

: Jika persegi panjang maka panjangnya $94 \mathrm{~cm}$ dan lebar $16 \mathrm{~cm}$ kemudian untuk segitiga sisi miringnya $20 \mathrm{~cm}$ dengan alas $12 \mathrm{~cm}$ dan tinggi 16 $\mathrm{cm}$, yang kedua segi panjang dengan panjang 38 $\mathrm{cm}$ dan lebar $32 \mathrm{~cm}$ untuk segitiga sisi miring 40 $\mathrm{cm}$ alas $24 \mathrm{~cm}$ dan tinggi $32 \mathrm{~cm}$

$\mathrm{M}$

: Apakah kamu yakin dengan langkah-langkah yang kamu pikirkan ? Mengapa?

A : Iya. Karena menurut saya itu lebih mudah

M : Apakah kamu hanya bisa menyebutkan 2 saja ya? A : Iya

Hal tersebut menunjukkan subjek AS sudah memiliki kefasihan dalam dirinya.

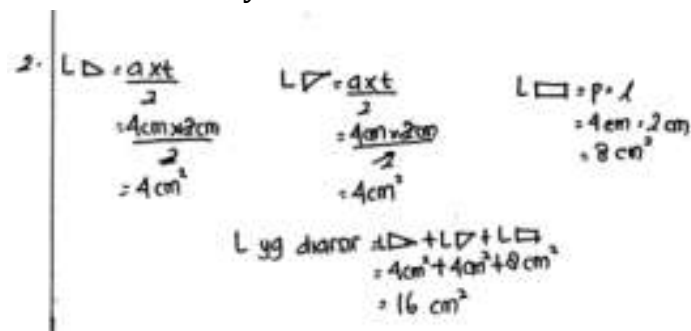

Gambar 5. Hasil Pekerjaan Soal No.2 
Kefasihan yang ditunjukkan dengan baik oleh subjek AS tidak diikuti oleh dua indikator lainnya yaitu fleksibilitas dan kebaruan. Subjek AS mengalami kesulitan dalam memberikan alternatif jawaban untuk menemukan luas yang diarsir yang dia buat seperti pada Gambar 5. Subjek hanya memberikan 1 luas gabungan saja. Hal ini diperkuat oleh wawancara sebagai berikut:

M : Coba ceritakan kembali apa yang kamu pahami dari soal tersebut!

A : (membaca soal no.2)

M : Apakah kamu bisa menyebutkan hal-hal yang diketahui dari soal?

A : : Iya

M : Apa saja yang ditanyakan dari soal tersebut?

A : Luas gambar yang diarsir

M : Pengetahuan apa saja yang kamu dapat gunakan untuk menjawab soal tersebut?

A : Menggunakan luas segitiga dan luas persegi panjang

M : Mengapa kamu memilih pengetahuan itu ?

A : Karena itu lebih mudah

M : Jelaskan langkah-langkah yang kamu gunakan untuk menjawab soal tersebut!

A

: Luas segitiga pertama $=\frac{a \times t}{2}=\frac{4 \mathrm{~cm} \times 2 \mathrm{~cm}}{2}=4 \mathrm{~cm}^{2}$, luas segitiga kedua $=\frac{a \times t}{2}=\frac{4 \mathrm{~cm} \times 2 \mathrm{~cm}}{2}=4 \mathrm{~cm}^{2}$, luas persegi panjang $=p \times l=4 \mathrm{~cm} \times 2 \mathrm{~cm}=8 \mathrm{~cm}^{2}$, luas yang diarsir luas segitiga pertama+luas segitiga kedua+luas persegipanjang = $4 \mathrm{~cm}^{2}+4 \mathrm{~cm}^{2}+8 \mathrm{~cm}^{2}=16 \mathrm{~cm}^{2}$

M : Apakah kamu yakin dengan langkah-langkah yang kamu pikirkan ? Mengapa?

A : Iya. Karena itu lebih mudah

M : Apakah kamu hanya bisa menyebutkan 1 saja ya? A : Iya

Berdasarkan hal tersebut menunjukkan bahwa subjek AS belum memiliki fleksibilitas dalam dirinya.

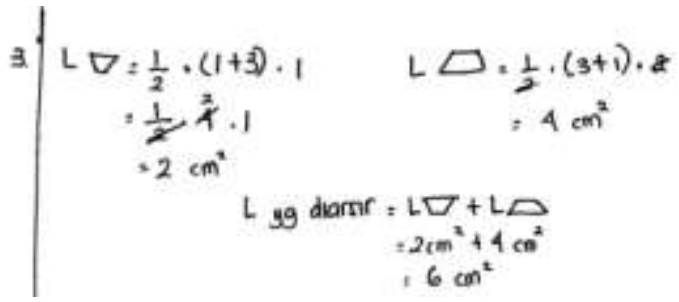

Gambar 6. Hasil Pekerjaan Soal No.3

Sama halnya dengan indikator fleksibilitas, subjek AS juga belum mampu memberikan sesuatu yang baru dan berbeda, seperti yang terlihat pada Gambar 6, subjek AS hanya memberikan jawaban yang terbilang masih umum dan belum baru. Hal ini diperkuat dengan wawancara sebagai berikut:

M : Coba ceritakan kembali apa yang kamu pahami dari soal tersebut!

A : (membaca soal no.3)

M : Apakah kamu bisa menyebutkan hal-hal yang diketahui dari soal?

: Iya

: Apa saja yang ditanyakan dari soal tersebut?

: Menghitung luas yang diarsir

: Pengetahuan apa saja yang kamu dapat gunakan untuk menjawab soal tersebut?

: Menggunakan luas trapesium

: Mengapa kamu memilih pengetahuan itu?

: Karena lebih mudah

: Jelaskan langkah-langkah yang kamu gunakan untuk menjawab soal tersebut!

: Luas trapesium pertama $=\frac{1}{2} \times(1+3) \times 1=\frac{1}{2} \times$ $4 \times 1=2 \mathrm{~cm}^{2}$, luas trapesium kedua $=\frac{1}{2} \times$ $(1+3) \times 2=\frac{1}{2} \times 4 \times 2=4 \mathrm{~cm}^{2}$, luas yang diarsir luas trapesium pertama + luas trapesium kedua = $2 \mathrm{~cm}^{2}+4 \mathrm{~cm}^{2}=6 \mathrm{~cm}^{2}$

M : Apakah kamu yakin dengan langkah-langkah yang kamu pikirkan? Mengapa?

A : Iya. Karena lebih mudah

M : Apakah kamu hanya bisa menyebutkan 1 saja ya?

A : Iya

Hal tersebut subjek FQ tidak mampu membuat jawaban yang berbeda.

\section{Subjek WL memiliki tingkat kemampuan berpikir kreatif 0}

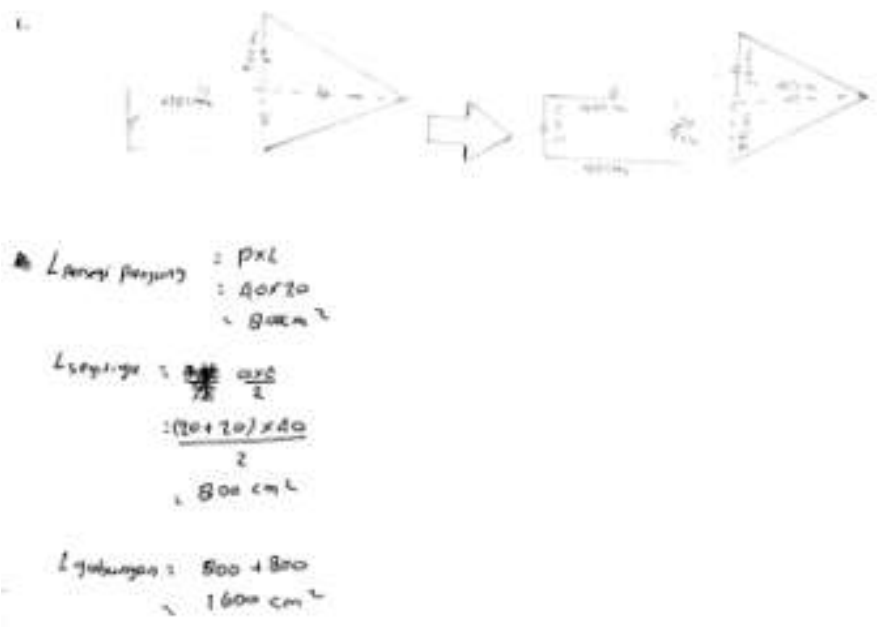

Gambar 7. Hasil Pekerjaan Soal No.1

Subjek yang termasuk dalam TKBK 0 (tidak kreatif), menunjukkan bahwa subjek belum mampu memunculkan ketiga indikator dari kemampuan berpikir kreatif. Subjek WL kesulitan saat harus memberikan jawaban yang bermacam-macam terlihat pada Gambar 7. Subjek WL hanya mampu menemukan 1 luas gabungan saja. Hal ini diperkuat oleh wawancara sebagai berikut:

M : Coba ceritakan kembali apa yang kamu pahami dari soal tersebut!

W

M : Apakah kamu bisa menyebutkan hal-hal yang diketahui dari soal? : Iya 
: Nama bangun dan penyusunnya beserta ukurannya

M : Pengetahuan apa saja yang kamu dapat gunakan untuk menjawab soal tersebut?

W

: Panjang dan lebar persegi panjang serta alas dan tinggi segitiga

M : Mengapa kamu memilih pengetahuan itu ?

W : Karena itu sangat mudah

M : Jelaskan langkah-langkah yang kamu gunakan untuk menjawab soal tersebut !

: Luas persegi panjang $=p \times l=40 \times 20=$ $800 \mathrm{~cm}^{2}$, luas segitiga $=\frac{1}{2} \times a \times t=\frac{(20+20) \times 40}{2}=$ $800 \mathrm{~cm}^{2}$, luas gabungan $=800 \mathrm{~cm}^{2}+800 \mathrm{~cm}^{2}=$ $1600 \mathrm{~cm}^{2}$

M : Apakah kamu yakin dengan langkah-langkah yang kamu pikirkan? Mengapa?

W : Yakin. Karena itu sangat mudah

M : Apakah kamu hanya bisa menyebutkan 1 saja ya? W : Iya

Hal tersebut menunjukkan bahwa subjek WL belum mampu memberikan bermacam-macam jawaban sehingga indikator kefasihan belum mampu dimunculkan.

$$
\text { 2. } \begin{aligned}
l_{\text {ppb }} & =p \times c \\
& =8 \times a \\
& =32 \mathrm{~cm}^{2} \\
l_{s}=\frac{a \times 6}{2} & =\frac{9 \times 9}{2} \\
& =\frac{16}{2} \mathrm{~cm}^{2} \\
& =\theta^{2}
\end{aligned}
$$$$
L_{\text {ppu }}=p \times c
$$$$
4 / \mathrm{t}
$$$$
58 \mathrm{~cm}^{2}
$$

Gambar 8. Hasil Pekerjaan Soal No.2

Subjek WL juga kesulitan memberikan cara lain dalam menemukan luas yang diarsir, seperti yang terlihat pada Gambar 8. Subjek hanya bisa menemukan 1 luas gabungan saja. Hal ini diperkuat oleh wawancara sebagai berikut:

M : Coba ceritakan kembali apa yang kamu pahami dari soal tersebut!

W : (membaca soal no.2)

M : Apakah kamu bisa menyebutkan hal-hal yang diketahui dari soal?

W : Bisa

M : Apa saja yang ditanyakan dari soal tersebut?

W : Luas gambar yang diarsir

M : Pengetahuan apa saja yang kamu dapat gunakan untuk menjawab soal tersebut?

: Luas persegi panjang besar - luas segitiga + luas persegi panjang kecil

M : Mengapa kamu memilih pengetahuan itu ?

W : Karena itu mudah
M : Jelaskan langkah-langkah yang kamu gunakan untuk menjawab soal tersebut!

W : Luas persegi panjang besar $=p \times l=8 \times 4=32$, luas segitiga $=\frac{a \times t}{2}=\frac{4 \times 4}{2}=\frac{16}{2}=8$, luas persegi panjang kecil $=p \times l=4 \times 2=8$, luas yang diarsir $32-(8+8)=16$

M : Apakah kamu yakin dengan langkah-langkah yang kamu pikirkan ? Mengapa?

W : Yakin. Karena itu mudah

M : Apakah kamu hanya bisa menyebutkan 1 saja ya ? W : Iya

Berdasarkan hal tersebut menunjukkan bahwa subjek WL belum memiliki fleksibilitas dalam dirinya.
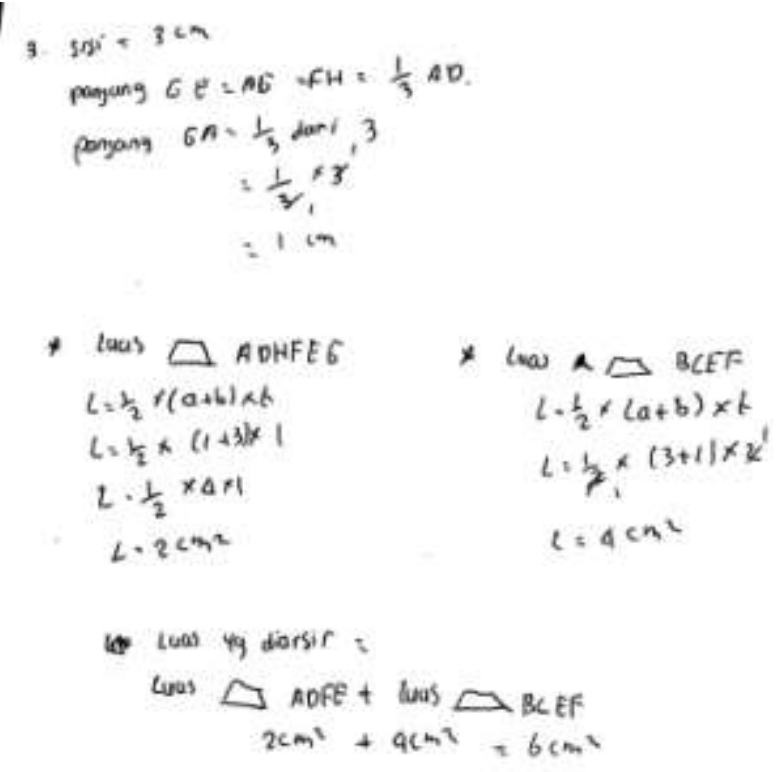

Gambar 9. Hasil Pekerjaan Soal No.3

Subjek WL juga belum mampu memberikan sesuatu yang baru dan berbeda, seperti yang terlihat pada Gambar 9, subjek WL hanya memberikan jawaban yang terbilang masih umum dan belum baru. Hal ini diperkuat dengan wawancara sebagai berikut:

M : Coba ceritakan kembali apa yang kamu pahami dari soal tersebut!

W : (membaca soal no.3)

M : Apakah kamu bisa menyebutkan hal-hal yang diketahui dari soal ?

W : Bisa

M : Apa saja yang ditanyakan dari soal tersebut ?

W : Luas yang diarsir

M : Pengetahuan apa saja yang kamu dapat gunakan untuk menjawab soal tersebut?

W : Luas ADHFEG dan luas BCEF

$\mathrm{M} \quad$ : Mengapa kamu memilih pengetahuan itu?

W : Karena itu mudah

M : Jelaskan langkah-langkah yang kamu gunakan untuk menjawab soal tersebut !

W

: Luas trapesium $\mathrm{ADEF}=\frac{1}{2} \times(a+b) \times t=\frac{1}{2} \times$ $(1+3) \times 1=\frac{1}{2} \times 4 \times 1=2 \mathrm{~cm}^{2}$, dan luas trapesium $\mathrm{BCEF}=\frac{1}{2} \times(a+b) \times t=\frac{1}{2} \times(1+3) \times$ 
$2=4 \mathrm{~cm}^{2}$, luas yang diarsir trapesium ADFE+luas trapesium $B C E F=2 \mathrm{~cm}^{2}+4 \mathrm{~cm}^{2}=6 \mathrm{~cm}^{2}$

M : Apakah kamu yakin dengan langkah-langkah yang kamu pikirkan ? Mengapa?

W : Iya. Karena itu mudah

M : Apakah kamu hanya bisa menyebutkan 1 saja ya ? W : Iya

Hal tersebut subjek WL tidak mampu membuat jawaban yang berbeda.

\section{SIMPULAN DAN SARAN}

Dari hasil penelitian dan pembahasan yang telah diuraikan maka diperoleh simpulan bahwa siswa berkemampuan tinggi dalam proses menyelesaikan soal berpikir kreatif luas gabungan dengan tiap tingkat berpikir kreatif mampu memunculkan satu indikator kemampuan berpikir kreatif yaitu fleksibilitas, subjek mampu memberikan lebih dari satu alternatif jawaban secara baik. Sedangkan siswa berkemampuan sedang dalam proses menyelesaikan soal berpikir kreatif luas gabungan dengan tiap tingkat berpikir kreatif mampu memunculkan indikator kemampuan berpikir kreatif yaitu kefasihan, subjek dengan fasih dapat menyelesaikan soal dengan bervariasi jawaban. Dan untuk siswa berkemampuan rendah dalam proses menyelesaikan soal berpikir kreatif luas gabungan dengan tiap tingkat berpikir kreatif tidak mampu memunculkan ketiga indikator kemampuan berpikir kreatif dengan baik; kefasihan, fleksibilitas dan kebaruan belum mampu terlihat dari jawaban yang diberikan oleh subjek.

Berdasarkan simpulan diatas adapaun saran untuk peneliti lain, guru, dan siswa. Bagi guru perlu mempersiapkan diri untuk memberikan perlakuan yang sesuai terhadap siswa dengan memperhatikan tingkat kemampuan berpikir kreatif siswa, sehingga siswa lebih mampu mengembangkan berpikir kreatifnya. Bagi peneliti lain agar dapat mengembangkan indikator tingkat berpikir kreatif secara lebih spesifik untuk memudahkan menilai berpikir kreatif siswa. Bagi siswa hendaknya kreativitas yang dimiliki terus diasah sehingga mampu membantu siswa itu sendiri dalam menyelesaikan berbagai soal.

\section{UCAPAN TERIMA KASIH}

Penulis mengucapkan terima kasih kepada dosen pembimbing, validator, guru matematika, serta siswa SMP Negeri 8 Salatiga yang telah membantu dalam menyelesaikan penelitian ini.

\section{DAFTAR RUJUKAN}

[1] Hartono. 2009. Perbandingan Peningkatan Kemampuan Berpikir Kreatif dan Aplikasi Matematika Siswa pada Pembelajaran Open-Ended dengan Konvensional di Sekolah Menengah Pertama. Disertai Doktor pada SPS. Bandung: UPI
[2] Mahmudi, Ali. 2010. Mengukur Kemampuan Berpikir Kreatif Matematis.Makalah pada Konferensi Nasional Matematika XV. FMIPA Universitas Negeri Yogyakarta.

[3] Kemendikbud. 2014. Materi Pelatihan Guru Implementasi Kurikulum 2013 Tahun Ajaran 2013/2014. Jakarta: Badan Pengembangan Sumber Daya Manusia Pendidikan dan Kebudayaan dan Penjamin Mutu Pendidikan.

[4] Livne, N.L. (2008). Mengukur Kemampuan Berpikir Kreatif Matematis. Makalah pada Konferensi Nasional Matematika XV. FMIPA Universitas Negeri Yogyakarta.

[5] Silver, E.A. 1997. Fostering Creativity through Instruction Rich in Mathematical Problem Solving and Problem Posing. Zentralblatt fur Didaktik der Mathematik (ZDM)- The International Journal on Mathematic Education (Online). Tersedia: http://emis.de/journals/ZDM/zdm973a3.pdf

[6] Siswono, Tatag Yuli Eko. 2008. Model Pembelajaran Berbasis Pengajuan dan Pemecahan Masalah Untuk Meningkatkan Kemampuan Berpikir Kreatif. Surabaya : Unesa University Press.

[7] Siswono. 2011. ANALISIS TINGKAT KEMAMPUAN BERFIKIR KREATIF PESERTA DIDIK DALAM MEMECAHKAN MASALAH GEOMETRI DITINJAU DARI GAYA BELAJAR. KELAS X MATEMATIKA ILMU ALAM. (MIA) 4 SMA NEGERI 2 SRAGEN. TAHUN PELAJARAN 2014/2015. Jurnal FKIP UNS. Online. Tersedia. https://media.neliti.com/media/publications/123177ID-analisis-tingkat-kemampuan-berfikir-krea.pdf.

[8] Sugiyono. 2012. Metode Penelitian Pendidikan Pendekatan Kuantitatif, Kualitatif, dan R\&D. Bandung : Alfabeta.

[9] Usman, M.R. 2014. Meningkatkan Kemampuan Berpikir Kreatif dan Komunikasi Serta Disposisi Berpikir Kreatif Matematis Siswa SMP melalui Pembelajaran Inkuiri Model Alberta. Tesis, Sekolah Pascasarjana, Universitas Pendidikan Indonesia. 